\title{
エネルギ解放率破壊規準による 長さの異なる平行き裂の進展挙動について
}

阿 部 孝 弘 $^{*}$ 矢 富 盟 祥**
橋 本 堅 —** 山 本 将 司

The Extension Behavior of Parallel Cracks

Based on the Energy Release Rate Criterion

by

\author{
Takahiro ABE ${ }^{*}$, Chikayoshi Yatomi ${ }^{* *}$, \\ Ken-ichi Hashimoto ${ }^{* * *}$ and Syouji Yamamoto ${ }^{* * * *}$
}

\begin{abstract}
In this paper, we examine the crack extension behavior for a linear elastic body with two parallel cracks. Assuming the isotropy of fracture toughness of the body and judging from the criterion based on the energy release rate, we study the influences of the difference of crack length, the relative position of cracks and the load angle on crack extension behavior. The energy release rate is computed for all the extending crack tips at the onset of crack kinking by using the E-integral which is path independent even for a path containing a kinking crack tip and stationary crack tips.
\end{abstract}

Key words : Crack extension, Energy release rate, E-integral, Crack interaction, Parallel cracks, Plane stress, FEM

\section{1 緒言}

き裂干渉問題は，セラミックス，岩石およびコンクリ 一トなどの初期微小き裂を有する材料の耐久性，安全性 を把握するために非常に重要な課題であるため，多くの 研究成果が報告されている，しかし，き裂干渉問題の解 析には，複数個存在するき裂先端の中でどの先端がどの 方向に進展するかを把握する必要があるため，解析的あ るいは数值的に処理することには多くの困難と煩わしさ を伴うことが多い. 1983 年にYatomi ${ }^{11}$ にっつて提案され たエネルギ解放率を求めるための経路独立な積分である $\mathrm{E}$ 積分は，き裂進展後の応力解析を行なう必要はあるが, 周知の $\mathrm{J}$ 積分と異なり，準静的なき裂進展である限り， 経路内に進展き裂以外のき裂先端やひずみの不連続面を 含んでいても，き裂が折れ曲がり進展する瞬間時のエネ ルギ解放率を求めることができる。そのため $\mathrm{E}$ 積分はき 裂干渉問題には非常に有効な手段であるといえる，また， $\mathrm{E}$ 積分では全く任意の積分経路を選択できることから， 誤差を含みやすいき裂先端近傍における応力などの物理 量を使わずに評価できるため，有限要素法による解析を 行なう場合，き裂先端に特異要素を用いることなく解析 できる.

著者らはこれまでにき裂面に対して垂直の方向に一様
引張（垂直荷重と呼ぶことにする）を受ける帯板中央に 主き裂があり，その近傍にそれより長さの短い平行干涉 き裂が存在する場合のき裂進展挙動を $\mathrm{E}$ 積分により解析 し，干渉き裂の位置によって主き裂の進展が抑制，助長

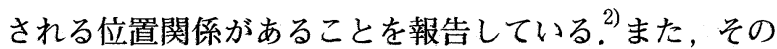
場合の実験結果との比較も報告している. ${ }^{3)}$ 本研究では, まず，垂直荷重が作用する帯板内に，等長な 2 本の平行 き裂がある場合のエネルギ解放率を $\mathrm{E}$ 積分によって求め, アクリル板を用いた実験結果と比較検討する。次に 2 本 のき裂長さに差があり，き裂面に対して傾斜した引張荷 重（斜向荷重と呼ぶことにする）が作用する場合のき裂 進展挙動を $\mathrm{E}$ 積分によって求めたエネルギ解放率の解析 結果から考察する.

き裂進展に関する破壊規準は材料によって異なると考 えられるが, 本研究では, き裂の進展はエネルギ解放率 による破壊規準によるものと仮定し, 材料の破壊じん性 値の等方性を仮定した.

\section{$2 \cdot 1$ 解析方法}

\section{2 解析方法と解析モデル}

物質内に複数のき裂が存在する場合，き裂相互の干渉 によって, き裂の進展が助長され，材料の見かけ上の強 度が小さくなる場合や，逆にき裂の進展が抑制され，材

原稿受理 平成 13 年 6 月 8 日 Received June 8,2001

正 会 員 福井工業高等專門学校環境都市工学科 ₹916-8507 鯖江市下司町, Dept. of Civil Eng., Fukui National College of Tech., Geshi-

* 正 会 員 福井工業高垔

** 正 会 員、金沢大学工学部土木建設工学科 F920-8667 金沢市小立野, Dept. of Civil Eng., Kanazawa Univ., Kodatsuno, Kanazawa, 920-8667

*** 正 会 員 徳山工業高等専門学校土木建築工学科 干 745-8585 徳山市久米高城, Dept. of Civil Eng., Tokuyama College of Tech., Kumetakjou, Tokuyama, 745-8585

**** 金沢大学大学院 $\quad$ T920-8667 金沢市小立野, Graduate Student., Kanazawa Univ., Kodatsuno, Kanazawa, 920-8667 
料の見かけ上の強度が大きくなる場合がある，また，直 進ではなく折れ曲がって進展する場合が多く，き裂進展 挙動は非常に複雑な問題となる.

そこで, 本研究では複数き裂の最も基本的なモデルと して, 平面応力問題において, 均質な等方線形弾性体中 に 2 本のき裂が平行な位置関係で存在する場合を考え， き裂の位置関係，き裂長さの僅かな差違および荷重の載 荷角度が，き裂の進展挙動にどのような影響を及ぼすの かを検討した。 また, エネルギ解放率は前述の理由によ り, $\mathrm{E}$ 積分を用いて求めた。ここに，き裂進展挙動とは， 複数個存在するき裂先端の中で, 与えられた条件下でど の先端がどの方向に進展する可能性が大きいかを把握す ることを意味する。

本研究では, 線形弾性体を対象としたため, き裂進展 によるエネルギ解放率を求める $\mathrm{E}$ 積分公式は, 次式で与 えられる.

$$
E(l)=\frac{1}{2} \int_{\Gamma}\left(s \cdot \frac{\partial u}{\partial l}-u \cdot \frac{\partial s}{\partial l}\right) d \Gamma
$$

ここで，「は進展き裂先端を含む領域の境界， $\boldsymbol{s}, \boldsymbol{u}$ は $\Gamma$ 上での表面応力ベクトルおよび変位べクトルであり,$l$ は き裂長さである。式 (1)を有限要素法に適用するため，1 に関する微分項を, き裂進展前と進展後の值で 2 点差分 近似すると，

$$
\begin{aligned}
E=\frac{1}{2} \sum_{i=1}^{n}\left\{s_{i}(l)\right. & \cdot \frac{u_{i}(l+\Delta l)-u_{i}(l)}{\Delta l} \\
& \left.-\frac{s_{i}(l+\Delta l)-s_{i}(l)}{\Delta l} \cdot u_{i}(l)\right\}
\end{aligned}
$$

となる. 式 (2)で $n$ は経路における節点の数, $\boldsymbol{s}_{i}$ は積分 経路上の節点力ベクトル， $\boldsymbol{u}_{i}$ は節点変位べクトルである. $\Delta l$ はき裂進展長さであり， $\phi(l)$, および $\phi(l+\Delta l)$ は，そ れぞれ，き裂進展前と進展後のモデルの物理量 $\phi$ を表す. $\mathrm{E}$ 積分では，き裂進展前と進展後のモデルについて有限 要素解析を行い，それぞれで得られた積分経路上の物理 量を式 (2)に代入しエネルギ解放率を求める。進展後に おいてき裂先端を折れ曲がらせた要素分割を用いること により，折れ曲がり瞬間時のエネルギ解放率が求まる.

\section{$2 \cdot 2$ 解析モデル}

解析を行ったモデルは Fig. 1 に示すように, 横幅 W の 無限長帯板中央に平行な 2 本のき裂 $\mathrm{A}, \mathrm{B}$ が存在する場 合を想定し，載荷角度 $\gamma$ の斜向荷重を受けるものとした.

き裂長さとき裂配置の位置関係の僅かな違いがき裂進 展挙動へどのような影響を及ぼすか検討するため, まず 最初に, 載荷角度 $\gamma=90^{\circ}$, すなわち垂直荷重を受ける 状態で，上側のき裂 $\mathrm{A}$ の水平方向（き裂面方向）の位置, および長さ $2 \mathrm{a}$ を固定し, 下側のき裂 $\mathrm{B}$ の長さ $2 \mathrm{~b}$ を変え たときに拈ける, き裂 $\mathrm{B}$ の右先端が折れ曲がり進展する 瞬間時のエネルギ解放率を $\mathrm{E}$ 積分により求めた. このと き， A， B 両き裂の左端の水平方向の位置は固定した. また， 2 本のき裂の鉛直方向（き裂面方向と直角な方向） の間隔 $h$ (以後, 鉛直き裂間隔と呼ぶ）を変化させた場 合についても同様の解析を行った. 次に斜向荷重が作用

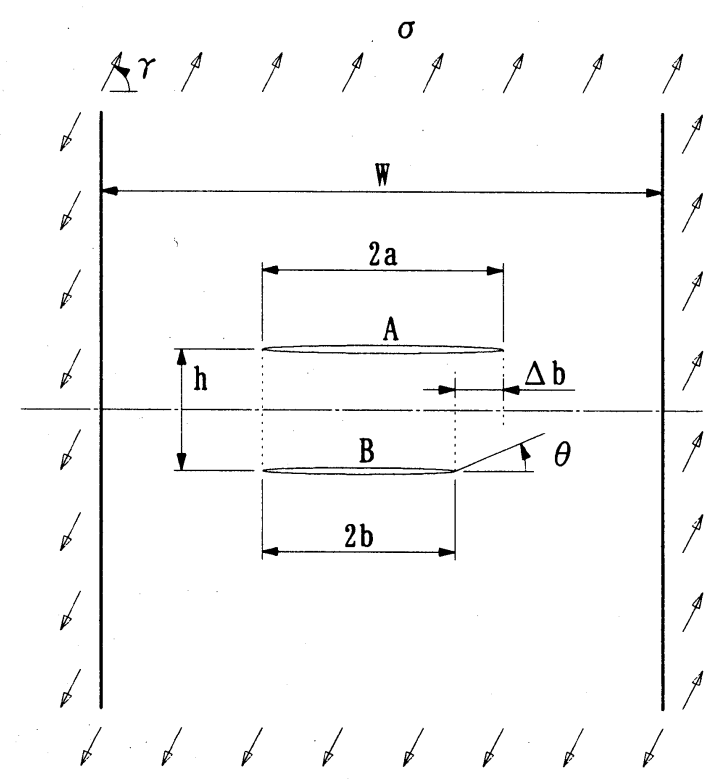

Fig. 1. Parallel two cracks.

する場合に，全てのき裂先端におけるエネルギ解放率を算 出し, エネルギ解放率最大の破壊規準に従って検討した.

解析に用いた有限要素近似モデルは, Fig. 2 に示す分 割で帯板幅 $\mathrm{W}=10 \mathrm{~cm}$, 縦方向の長さを $17.32 \mathrm{~cm}$ とし， 正三角形を基本とした定ひずみ三角形要素を用い, 正三 角形の大きさを縦方向で変えて 3 層に分けた分割とした. き裂の入る中央部分は, 横方向 160 等分割, 縦方向 48 等分割とし，積分経路は 5 本の経路を設定した。き裂進 展方向は $0^{\circ}, \pm 15^{\circ}, \pm 30^{\circ}, \pm 45^{\circ}, \pm 60^{\circ}, \pm 75^{\circ}, \pm 90^{\circ}$ の 13 方向とした.

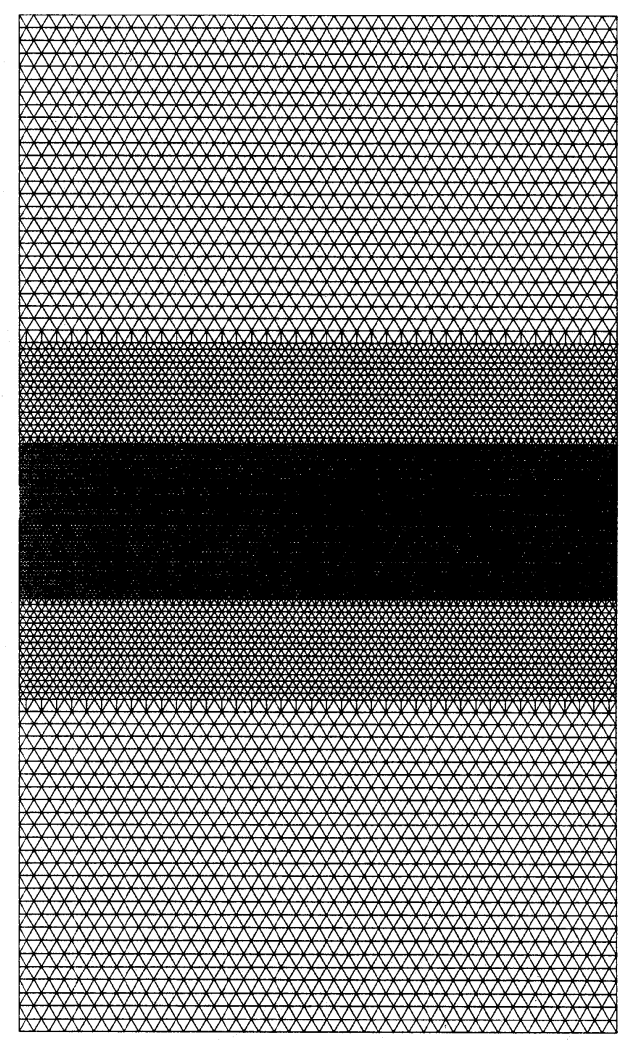

Fig. 2. Finite element model. 


\section{3 結 果 と考 察}

\section{$3 \cdot 12$ 本のき裂長さが異なる場合の進展き裂先端に おける結果と考察}

$3 \cdot 1 \cdot 1 \mathrm{E}$ 積分による解析結果 Fig. 3 は, 載荷角 度を $90^{\circ}$,すなわち, 垂直荷重を受けるものとし, き裂 $\mathrm{A}$ の長さ $2 \mathrm{a} を 2 \mathrm{~cm}$, 鉛直き裂間隔 $\mathrm{h}$ を $0.22 \mathrm{~cm}$ とし, き 裂 $\mathrm{B}$ の長さ $2 \mathrm{~b}$ をき裂 $\mathrm{A}$ と等長の場合打よび等長からそ れぞれ $0.0625 \mathrm{~cm}, 0.125 \mathrm{~cm}$ 増減させた場合の，き裂長さ を変えたき裂 $\mathrm{B}$ 右先端の $\mathrm{E}$ 積分によるエネルギ解放率の 解析結果である。ただし，縦軸は $\mathrm{E}$ 積分による算出值を 無限板中央にき裂 $\mathrm{A}$ と同じ長さのき裂が 1 本だけあり， それが直進進展するときの解析解 ${ }^{5}$ で除して正規化して ある。横軸は折れ曲がり角度 $\theta$ (上向きを正とする) で ある。

Fig. 3 から, き裂 B が長いほどエネルギ解放率は大き

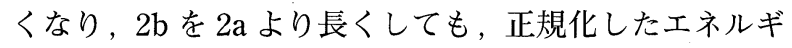
解放率の最大值は 1.0 を下回っている。したがって, 今 回の範囲でのき裂長さの違いならば，たとえ，き裂 Bの

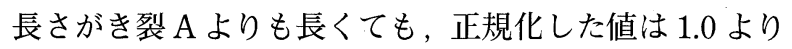
小さく, 平行なき裂では, き裂が 1 本の場合より 2 本の 場合の方が, 材料の荷重方向の見かけの引張破壊強度は 大きくなる傾向があると言える。また，き裂長さが $0.0625 \mathrm{~cm}$ 異なるだけで, 正規化したエネルギ解放率最大 の值は $0.14 \sim 0.23$ 程度変化し, エネルギ解放率は 2 本 のき裂長さの差の変化に敏感であると推測できる. 等長 の場合き裂先端近傍では，互いのき裂の存在により応力 の伝達が遮断される。片方のき裂が長ければ，長いき裂 先端は他方よりも右に存在することから, 遮断の影響が 小さくなる。このことによりエネルギ解放率の大きさが 変化する. エネルギ解放率が最大となる方向は, き裂 $\mathrm{B}$ の長さがき裂 $\mathrm{A} よ り$ 短いとき, $-15^{\circ}$ と下向きであるが， き裂 $\mathrm{A}$ と等長になり，き裂 $\mathrm{A}$ より長くなるほど， $-15^{\circ} に$ 比べ $0^{\circ}$ の值が大きくなり，き裂長さが大きくなるほど，

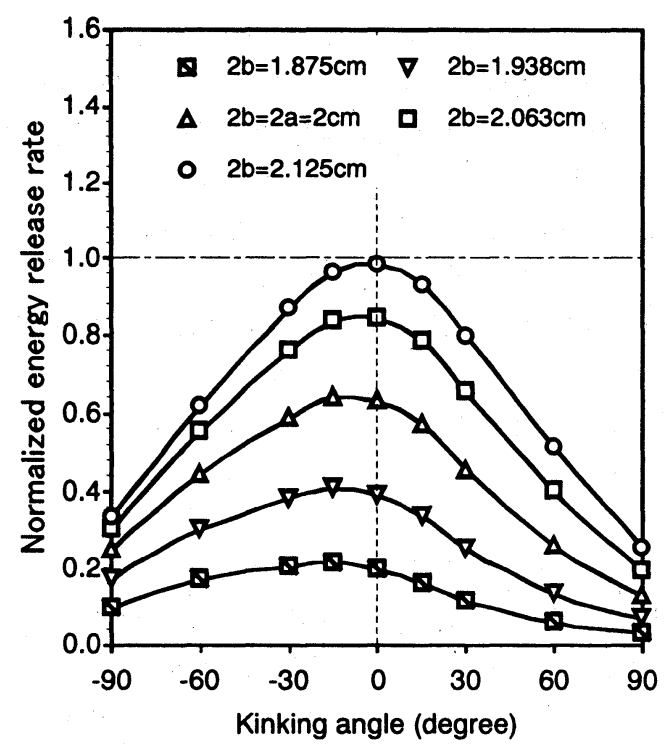

Fig. 3. The variations of energy release rate of a right side tip of crack $\mathrm{B} ; 2 \mathrm{a}=2 \mathrm{~cm}, \mathrm{~h}=0.22 \mathrm{~cm}$.
その直進性は顕著になると言える。このことも，き裂 $\mathrm{B}$ 右先端の水平方向の位置がき裂 $\mathrm{A}$ 右先端よりも右に存在 することによる。

き裂進展挙動を把握するためには，各き裂配置（き裂 長さおよびき裂の位置関係）に㧍いてのエネルギ解放率の 最大值打よびその方向が重要となる。そこで，各き裂配 置打けるエネルギ解放率を Emax とし，以降この Emax によって考察を行なう。

Fig. 4 は，き裂 $\mathrm{B}$ の長さの増減によるき裂 $\mathrm{B}$ 右先端 の $\mathrm{Emax}$ の変化を鉛直き裂間隔 $\mathrm{h}$ ごとに表したものであ る. 縦軸は $2 \mathrm{~b}=2 \mathrm{a}$ の場合の Emax を基準とした相対的 な増減割合であり，横軸はき裂 $\mathrm{B}$ の長さの増減分 $\Delta \mathrm{b}$ を 2a で除して無次元化した值である. Fig. 4 で, Fig. 3 の 結果は, $\mathrm{h}=0.22 \mathrm{~cm}$ のときの曲線で表わされるが, この 曲線は傾きは大きく，き裂 $\mathrm{B}$ がき裂 $\mathrm{A}$ と等長のときから $0.0625 \mathrm{~cm}$ （Fig. 4 の横軸の大きさが $3.125 \%$ ）大きくした だけで Emax は $31.8 \%$ も増加し, 前述のように非常に敏 感であると言える. h が大きくなるにしたがい，き裂 $\mathrm{A}$ の影響か弱まるため, き裂長さの増加による Emax の増 加割合は小さくなり, $\mathrm{h}$ を $2.17 \mathrm{~cm}$ としたときのそれは $5.4 \%$ と僅かになった。

Fig. 5 は, h の増加による Emax の変化をき裂 B の長 さごとに表わしたものである。横軸は h/2aである. h の 小さい， A，B両き裂が接近した状態では，き裂長さの 違いによるエネルギ解放率の差は著しく敏感だが，2つ のき裂が離れるにしたがい，穴の影響は小さくなり，収 束していくという自明の結果が得られた。しかし，き裂 $\mathrm{B}$ の長さがき裂 $\mathrm{A}$ と等長あるいは長い場合に $\mathrm{h}$ の増加に 伴って Emax に極小值が存在するという興味深い結果が 得られた。これらの解析を $2 \mathrm{a}$ の值を $1.5 \mathrm{~cm}, 1.0 \mathrm{~cm}$ と変 えて行っても, 同様の結果が得られた。

$\mathrm{h}$ の増加に伴い，極小值が存在することを等長の場合 で考察すると，h がかなり大きい場合には，き裂相互の 影響がなくなり，き裂 1 本の場合に収束する．h が小さ

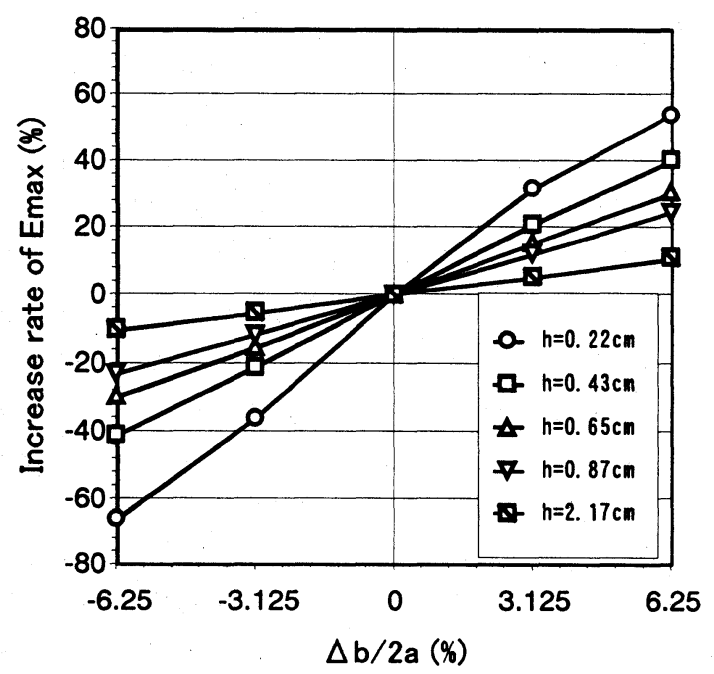

Fig. 4. The variations of the increase rate of Emax with the length of crack $B ; 2 a=2.0 \mathrm{~cm}$. 


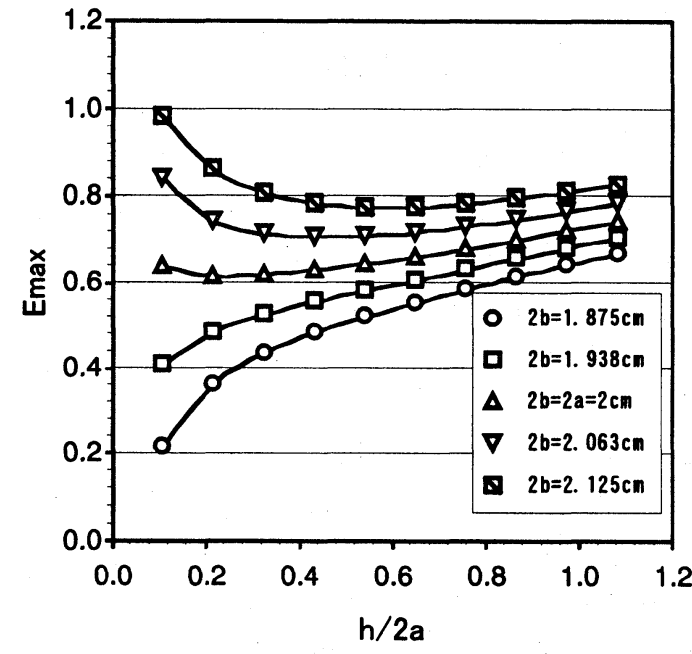

Fig. 5. The variations of Emax with $\mathrm{h} ; 2 \mathrm{a}=2.0 \mathrm{~cm}$.

い場合にはき裂相互の影響が大きくなり，進展が抑制さ れ，エネルギ解放率は減少する。しかし，さらに h が小 さい場合，すなわち $\mathrm{h} か ゙ 0$ になる極限を，2 本のき裂が 1本となると考えれば，エネルギ解放率は，h が非常に 小さい場合もき裂 1 本の状態に近づくことになる，き裂 長さが異なる場合には長い方のき裂 1 本に相当すること となる．その結果極小值が存在することになる：この現 象は興味深い事もあり, 次に, 実際にそのような傾向が あるか検証実験を行なった。

$3 \cdot 1 \cdot 2$ 実験結果と考察 実験は, $\mathrm{h}$ の小さい供試 体を加工することが困難なので, 縦横 $20 \mathrm{~cm}$, 厚さ $3 \mathrm{~mm}$ のアクリル板（アクリライト：三菱レイヨン製）に，2a $=2 \mathrm{~b}=4 \mathrm{~cm}, \mathrm{~h}$ を $0.5 \mathrm{~cm}, 1.0 \mathrm{~cm}, 3.0 \mathrm{~cm}$ としてき裂を挿 入した供試体をそれでれ 5 枚作成し, instron5581 型万 能試験機を用いて, 載荷速度 $0.1 \mathrm{~mm} / \mathrm{min}$ の変位制御で 引張試験を供試体が破断するまで行い, 最大荷重を求め た. き裂の挿入方法は, 刃幅 $0.4 \mathrm{~mm}$ 糸鋸を用いて所定 の位置に切り込みを入れた後，き裂先端を明確にするた め切り込み先端を, ピンバイスを用いて直径 $0.4 \mathrm{~mm}$ の円 弧とし，さらに工作用カッターで切欠を入れることとし た。”また，き裂 1 本の場合の引張実験も行なった。矢の 結果を Fig. 6 に示す。き裂挿入方法の影響で実験結果に は多少のバラッキが見られた。攵のため，Fig. 6 では 5 つの実験結果から最大拉よび最小を外した 3 つの平均を 取ってある。 また, 縦軸はき裂 1 本の実験結果の平均値 で除して無次元化した最大荷重値である.

Fig. 6 より最大荷重は, h の増加に伴って増加し, 再 び減少していることがわかる．すなわち，h の増加に伴 い，極大值が存在していることを表わしている．エネル キ解放率と最大荷重の関係を考光れば，エネルギ解放率 が大きいほどき裂が進展する可能性が大きくなり，見か け上の材料の強度は小さくなる。つまり, 最大荷重は小 さくなることを意味する。逆にエネルギ解放率が小さけ れば，最大荷重は大きくなる。したがって，Fig. 6 に極 大値が存在することは, Fig. 5 に極小值が存在すること の裏付けとなり, Fig. 5 に打ける解析結果の妥当性が検

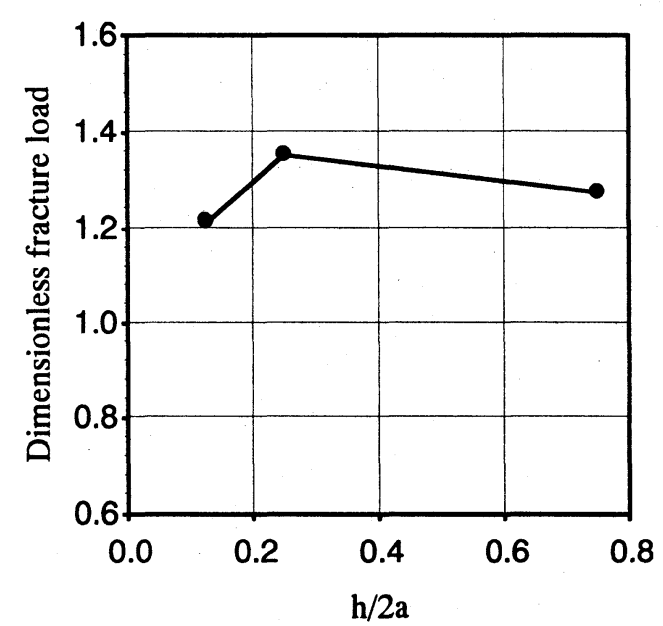

Fig. 6. The relationship between the fracture load and the crack interval for the experiment.

\section{証されたと言える.}

\section{$3 \cdot 2$ 斜向荷重が作用する場合の解析結果と考察}

2 本のき裂のうち, 一方のき裂長さを変化させ, 変化 させた方のき裂の先端でのエネルギ解放率を求め, 前述 の結果を得たわけであるが，一方のき裂の長さが短くな れば, 当然, 他方のき裂が進展する可能性が大きくなる. そこで次に，き裂 $\mathrm{B}$ の長さ $2 \mathrm{~b} ，$ および鉛直き裂間隔 $\mathrm{h}$ を変化させた幾つかのき裂配置において, き裂 $\mathrm{A}, \mathrm{B}$ の 左右両先端でのエネルギ解放率を求め, 一方のき裂の長 さの違いが，他方のき裂の進展挙動にどのような影響を 及ぼすのか検討することにした。また，荷重の載荷角度 $\gamma$ を変え, 載荷角度による影響についても合わせて考察 することにする。

Fig. 7 は $\gamma=90^{\circ}, 2 \mathrm{a}=2.0 \mathrm{~cm}$ とし， $2 \mathrm{~b}$ を $2 \mathrm{a}$ と等長と した場合および等長から $2 \mathrm{~b}$ を短くしていった場合にお ける, 各き裂先端での $\mathrm{E}$ 積分によるエネルギ解放率の解 析結果から得られた Emax の変化を示した。横軸はき裂 長さを変えたき裂 $\mathrm{B}$ の長さと固定したき裂 $\mathrm{A}$ の長さの比 $2 \mathrm{~b} / 2 \mathrm{a}$ である．鉛直き裂間隔 $\mathrm{h}$ を種々変化させて解析を 行ったが，ここでは $\mathrm{h}=0.22 \mathrm{~cm}(\mathrm{~h} / 2 \mathrm{a}=0.108)$ とした結 果を(a)に, $\mathrm{h}=2.17 \mathrm{~cm}(\mathrm{~h} / 2 \mathrm{a}=1.08)$ とした場合の結果を (b)に示した. また, 同じき裂配置で載荷角度を変えた, $\gamma=75^{\circ}$ の結果を Fig. 8 に, $\gamma=60^{\circ}$ の結果を Fig. 9 に示し た. また, Table Iにはこれらの解析結果から, き裂 $\mathrm{A}$ 両端においてエネルギ解放率が最大となったき裂折れ曲 がり角度を示した. Table I 中の太字はき裂 A 両先端で エネルギ解放率が大きい方の先端を表す.

ここで説明の都合上，き裂 $\mathrm{A}$ 右先端における $\mathrm{Emax}$ を 単にき裂 $\mathrm{A}$ 右と呼ぶことにする. 他の先端においても同 様である.

$\mathrm{h}$ の小さい Fig. 7 (a)では, 2 本のき裂長さが等しい $2 \mathrm{~b}$ $=2 \mathrm{a}(2 \mathrm{~b} / 2 \mathrm{a}=1.0)$ の場合は, 荷重状態, き裂配置が上下 対称になるため, 4 つのき裂先端におけるエネルギ解放 率は等しい. Table Iより，このとき，エネルギ解放率 が最大となる方向は, 上側にあるき裂 $\mathrm{A}$ は上向き $15^{\circ}$ で あるから，下側にあるき裂 B は下向き $15^{\circ}$ となる，き裂 


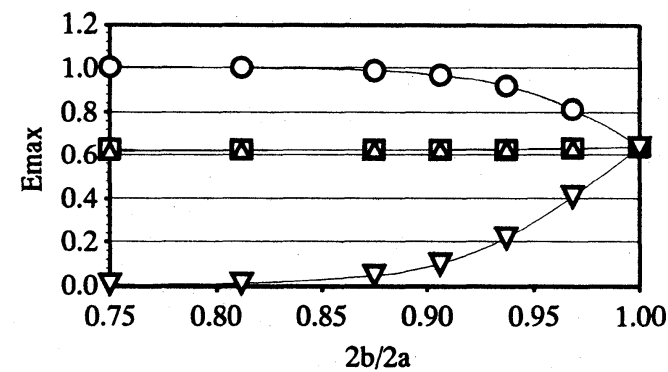

(a) $r=90^{\circ}, h / 2 a=0.108$

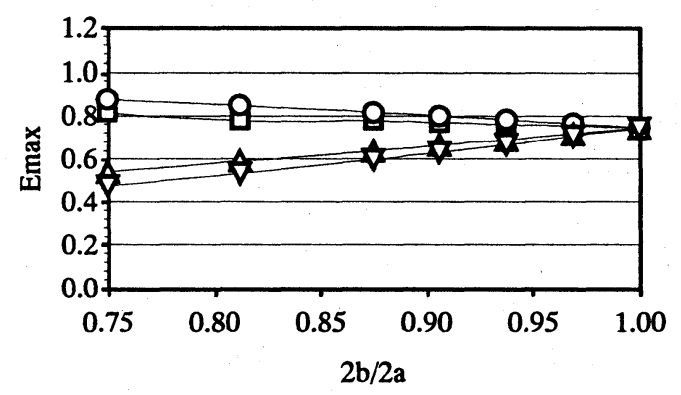

(b) $r=90^{\circ}, h / 2 a=1.08$

$\square$ crack $A$ left $O$ crack $A$ right

$\Delta$ crack B left $\nabla$ crack B right

Fig. 7. The variations of Emax for all crack tips $\left(\gamma=90^{\circ}\right)$.

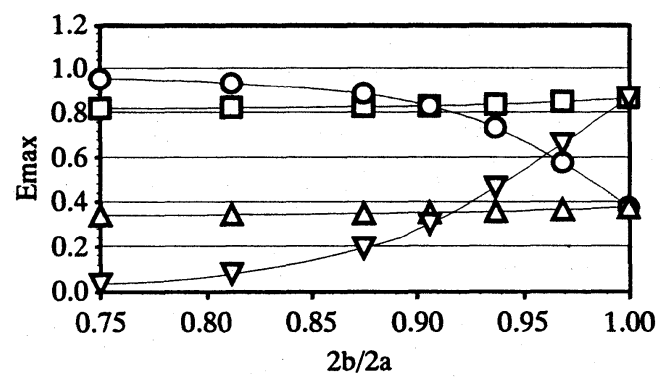

(a) $r=75^{\circ}, h / 2 a=0.108$

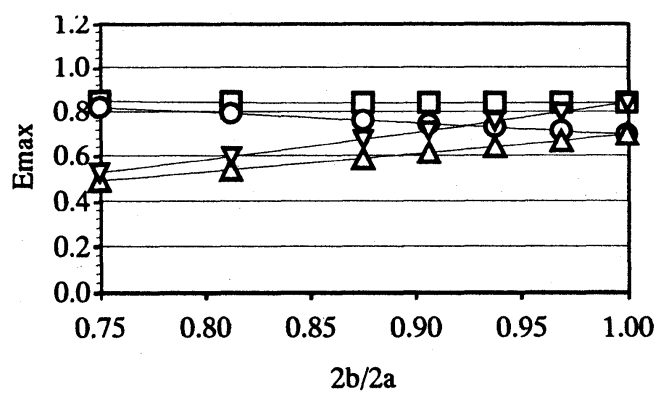

(b) $\gamma=75^{\circ}, h / 2 a=1.08$

$\square$ crack $A$ left $O$ crack $A$ right

$\Delta$ crack B left $\boldsymbol{\nabla}$ crack B right

Fig. 8. The variations of Emax for all crack tips $\left(\gamma=75^{\circ}\right)$.

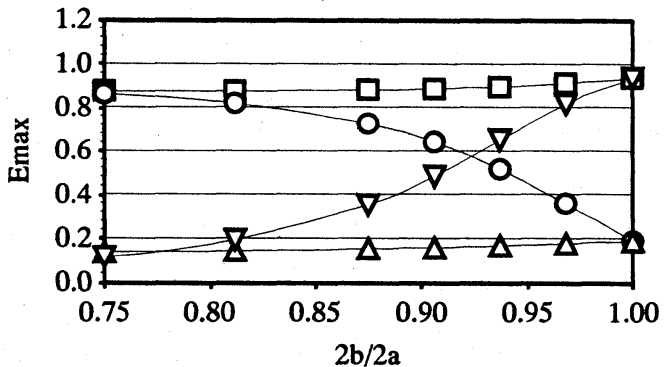

(a) $\gamma=60^{\circ}, \mathrm{h} / 2 \mathrm{a}=0.108$

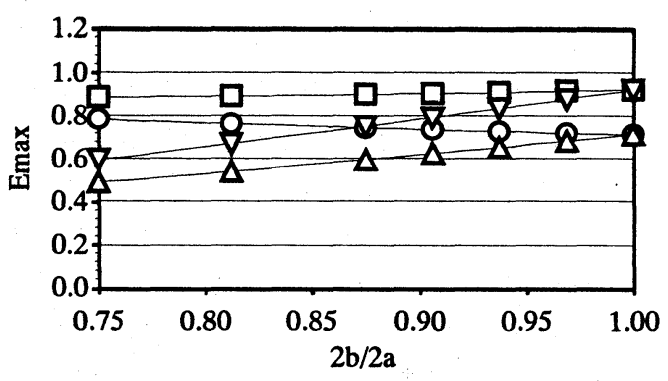

(b) $\gamma=60^{\circ}, h / 2 a=1.08$

ㄷak $A$ left $O$ crack $A$ right

$\Delta$ crack $B$ left $\boldsymbol{\nabla}$ crack $B$ right

Fig. 9. The variations of Emax for all crack tips $\left(\gamma=60^{\circ}\right)$.

Table I. The kinking angle for which the energy release rate takes the maximum.

\begin{tabular}{|c|c|c|c|c|c|}
\hline \multirow{3}{*}{$\begin{array}{c}\text { Load } \\
\text { angle } \\
\text { (degree) }\end{array}$} & \multirow{3}{*}{$2 b / 2 a$} & \multicolumn{4}{|c|}{ Kinking angle (degree) } \\
\hline & & \multicolumn{2}{|c|}{$h / 2 a=0.108$} & \multicolumn{2}{|c|}{$h / 2 a=1.08$} \\
\hline & & $\begin{array}{c}\text { crack } A \\
\text { left }\end{array}$ & $\begin{array}{c}\text { crack A } \\
\text { right }\end{array}$ & $\begin{array}{c}\text { crack } A \\
\text { left }\end{array}$ & $\begin{array}{c}\text { crack A } \\
\text { right }\end{array}$ \\
\hline \multirow{7}{*}{90} & 1.000 & 15 & 15 & 0 & $\mathbf{0}$ \\
\hline & 0.969 & 15 & $\mathbf{0}$ & 0 & $\mathbf{0}$ \\
\hline & 0.938 & 15 & $\mathbf{0}$ & 0 & 0 \\
\hline & 0.906 & 15 & $\mathbf{0}$ & 0 & 0 \\
\hline & 0.875 & 15 & $\mathbf{0}$ & 0 & $\mathbf{0}$ \\
\hline & 0.813 & 15 & $\mathbf{0}$ & 0 & $\mathbf{0}$ \\
\hline & 0.750 & 15 & $\mathbf{0}$ & 0 & $\mathbf{0}$ \\
\hline \multirow{7}{*}{75} & 1.000 & 15 & 0 & 30 & -15 \\
\hline & 0.969 & 15 & 0 & 30 & -15 \\
\hline & 0.938 & 15 & -15 & 30 & -15 \\
\hline & 0.906 & 15 & -15 & 30 & -15 \\
\hline & 0.875 & 15 & -15 & 30 & -15 \\
\hline & 0.813 & 15 & -15 & 30 & -15 \\
\hline & 0.750 & 15 & -15 & 30 & -15 \\
\hline \multirow{7}{*}{60} & 1.000 & 45 & -15 & 45 & -45 \\
\hline & 0.969 & 45 & -15 & 45 & -45 \\
\hline & 0.938 & 45 & -30 & 45 & -45 \\
\hline & 0.906 & 45 & -30 & 45 & -45 \\
\hline & 0.875 & 45 & -45 & 45 & -45 \\
\hline & 0.813 & 45 & -45 & 45 & -45 \\
\hline & 0.750 & 45 & -45 & 45 & -45 \\
\hline
\end{tabular}


$\mathrm{B}$ の長さが短くなるのに伴いき裂 $\mathrm{A}$ 右は大きくなり，き 裂 1 本の值 1.0 に収束していく．き裂 B 右は小さくなっ ていき，Emaxは0に収束する。また，き裂 $\mathrm{A}$ 左，き裂 B 左はあまり変化しない. 両き裂とも, 左先端に比べ, き裂長さを変化させた側の右先端におけるエネルギ解放 率の方がき裂長さの違いによるエネルギ解放率の変化が 著しく，エネルギ解放率の変化は，き裂長さの違いに依 存し, さらにき裂先端の水平方向の位置の違いがき裂進 展挙動に大きく影響を及ぼすことがわかる， $2 \mathrm{~b}$ を短くし ていった場合, 4 つのき裂先端中で, き裂 $\mathrm{A}$ 右が最大と なり，その方向は，Table Iよりほぼ直進方向となる.

hの大きな Fig. 7(b) では，Fig.7(a) と同様に等長の場 合には，すべての先端における Emax は等しいが，h が 小さい場合に比べて，前節で述べたように值は大きくな る。また，エネルギ解放率が最大となる方向はほぼ直進 となる．等長の場合から, $2 \mathrm{~b}$ を短くすると, Fig. 7(a) と 同様にき裂 $\mathrm{A}$ 右は大きくなり，き裂 $\mathrm{B}$ 右は小さくなる が, き裂相互の位置が離れているためその変化は緩やか であり，エネルギ解放率が最大となる方向も Table I よ りほほ直進となる。

$\gamma=75^{\circ}$ の場合の解析結果である Fig. 8 では, $2 \mathrm{~b}=2 \mathrm{a}$ のときには，き裂面に対する荷重方向が等しい先端であ る, き裂 $\mathrm{A}$ 左とき裂 $\mathrm{B}$ 右, およびき裂 $\mathrm{A}$ 右とき裂 $\mathrm{B}$ 左 がそれぞれ等しい值となる。そして載荷方向に対して鈍 角側のき裂先端であるき裂 $\mathrm{A}$ 左とき裂 $\mathrm{B}$ 右が大きい. $\mathrm{h}$ が小さいFig. 8 (a)で，2b を短くしていくと，き裂 $\mathrm{A}$ 左, き裂 $\mathrm{B}$ 左はあまり変化しないが, き裂 $\mathrm{B}$ 右は小さ く, き裂 $\mathrm{A}$ 右は大きくなっていく，そして，2bがある值 よりも小さくなると, き裂 $\mathrm{A}$ 右はき裂 $\mathrm{A}$ 左よりも大きく
なり，載荷方向よりもき裂長さの差の影響が大きくなる. エネルギ解放率が最大となる方向は，き裂 $\mathrm{A}$ 左が最大の ときは上向き $15^{\circ}$ であり，き裂 $\mathrm{A}$ 右が最大となるときは 下向き $15^{\circ}$ である.

h が大きいFig. 8(b)では, 鈍角側と鋭角側との差は小 さくなり，また， $2 \mathrm{~b}$ がある程度小さくなっても，き裂 $\mathrm{A}$ 右がき裂 $\mathrm{A}$ 左よりも大きくはならない，このとき，き裂 A 左が最大となり，その方向は，上向き $30^{\circ}$ であり，き 裂面に対する載荷角度が小さくなると，エネルギ解放率 が最大となる方向が大きくなる傾向にあるといえる。

$\gamma=60^{\circ}$ のときの結果である Fig. 9 では， $\gamma=75^{\circ}$ のとき とほぼ同様が得られたが，hが小さいときにも，き裂 $\mathrm{A}$ 左が最大となり, 載荷角度の影響が大きい. また，工ネ ルギ解放率が最大となる方向は, さらに大きくなった.

以上の結果より，エネルギ解放率が最大となるき裂先 端とその折れ曲がり角度の関係を描くと Table IIのよう になる.なお， $\gamma=45^{\circ}, 30^{\circ}$ としたときも $\gamma=60^{\circ}$ のとき 同様の結果が得られたが紙面の都合で省略する.

次に載荷角度と最大エネルギ解放率 $\mathrm{Emax}$ の関係を Fig. 10 に示す. Figs. 7，8，9 からわかるように4つの き裂先端でエネルギ解放率が最大となるのは，き裂長さ の長い，き裂 Aの先端であることから，Fig. 10 (a)には， 等長の場合 $(2 \mathrm{~b} / 2 \mathrm{a}=1.0)$ の各載荷角度におけるき裂 $\mathrm{A}$ 両端の Emax を, Fig. 10 (b)には $2 \mathrm{~b} / 2 \mathrm{a}=0.75$ の場合に ついての Emax を示した。 き裂 $\mathrm{A}$ 左は実線で，き裂 $\mathrm{A}$ 右 は破線で示してある.Fig. 10 (a)より，等長の場合は， き裂面に対して斜向荷重が作用すると，鉛直き裂間隔 $\mathrm{h}$ に差があっても，載荷角度に対して鈍角側にあるき裂 $\mathrm{A}$ 左が鋭角側にあるき裂 $\mathrm{A}$ 右より大きい。また，載荷角度

Table II . The predicted behavior of kinking angles.

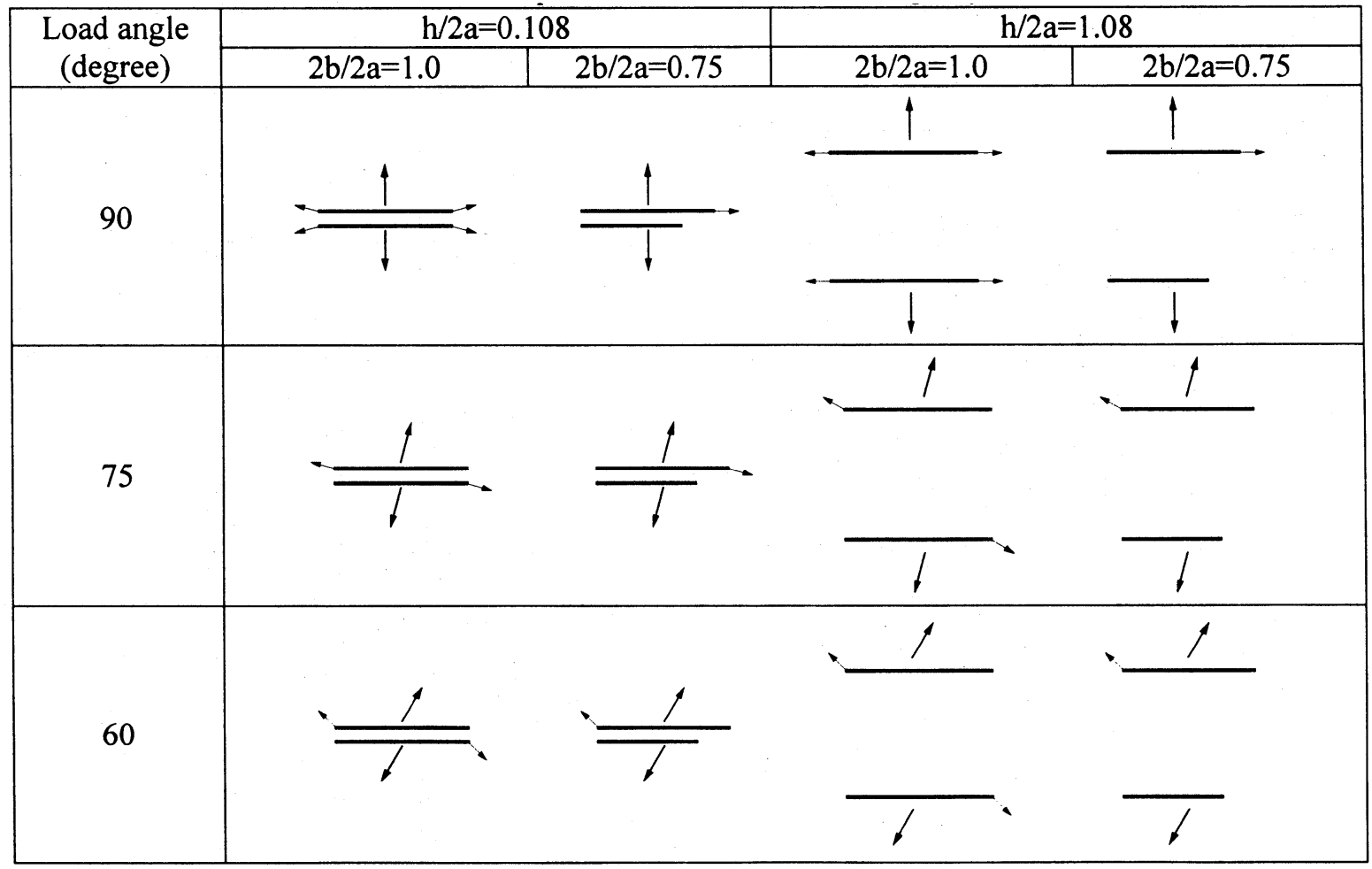




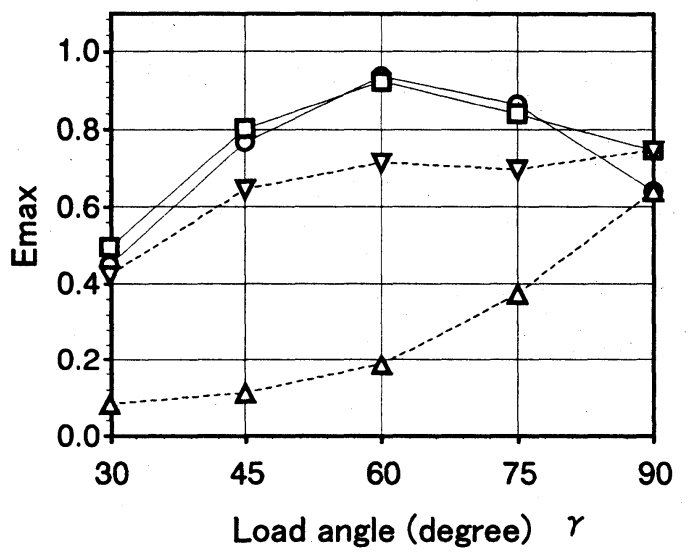

(a) $2 b / 2 a=1.0$

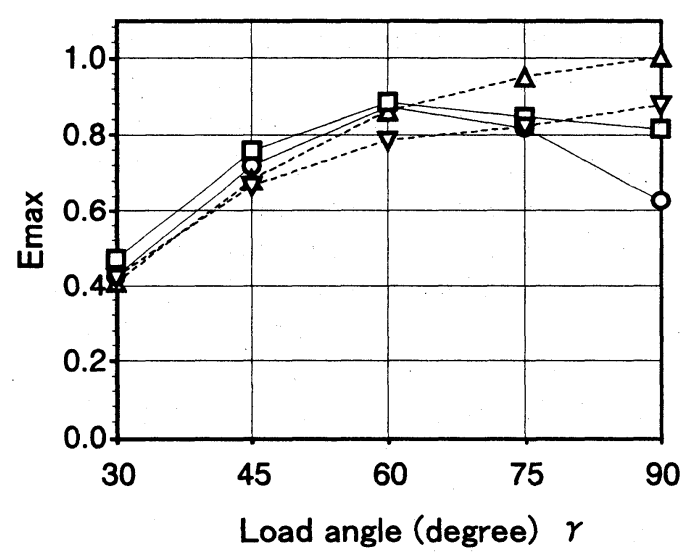

(b) $2 \mathrm{~b} / 2 \mathrm{a}=0.75$

\section{- left, $\mathrm{h} / 2 \mathrm{a}=0.108-\Delta \cdot$ right, $\mathrm{h} / 2 \mathrm{a}=0.108$}

- - left, $h / 2 \mathrm{a}=1.08 \quad-\nabla \cdot$ right, $h / 2 \mathrm{a}=1.08$

Fig. 10. The variations of Emax of crack $A$ with the load angles.

$60^{\circ}$ のときのき裂 $\mathrm{A}$ 左が最も大きいことから，き裂面に 対して $60^{\circ}$ の方向に引張力が作用するときにエネルギ解 放率が最大となる.

き裂長さに差のある Fig. 10 (b)では，き裂先端の水平 方向の位置を固定してある側であるき裂 $\mathrm{A}$ 左は載荷角度 に対して Fig. 10 (a)と同様な傾向を示すが，き裂 A 右は き裂 B の長さが短いことの影響を受けて，き裂面に対し
て垂直に近い引張荷重が作用する場合，き裂 A 左よりも 大きくなる．このことは，き裂長さの差がさらに大きく なれば顕著になると考えられる。載荷角度が小さい場合 にはき裂 A左とき裂 A 右には差がなくなる.

\section{4 結言}

本研究では, 線形弾性体中にある, 平行な 2 本のき裂 を想定し，き裂長さと位置関係，荷重状態の違いがき裂 の進展挙動にどのような影響を及ぼすか，き裂進展がエ ネルギ解放率による破壊規準に従うものと仮定して，解 析検討した。その結果，明らかになったことは以下の通 りである.

（1） 2 本のき裂が平行な位置関係で存在する場合，そ の進展挙動は, き裂長さの僅かな変化に対し, 敏感であ り，このことにはき裂先端の位置関係が影響する.

(2) 2 本のき裂の鉛直間隔が大きくなるにしたがい, き裂相互の影響は小さくなるという自明の結果が得られ， 解析の妥当性が検証された.

（3）き裂長さの差が大きい場合，鉛直間隔の増加に伴 い，工ネルギ解放率最大の值に極小值が存在する。この ことは実験を通して検証できた。

（4） 2 本のき裂が平行な位置関係で存在し，斜向荷重 を受けるとき，長い方のき裂の載荷方向に対して鈍角側 の先端のエネルギ解放率が最大となるが，載荷角度がき 裂面に対して $90^{\circ}$ に近いときには，き裂長さの影響で鋭 角側の先端が最大となる場合もある.

(5) き裂面に対して $60^{\circ}$ の方向に引張力が作用すると きにエネルギ解放率が最大となる.

（6）載荷角度に対して，エネルギ解放率が最大となる き裂先端およびその方向を明らかにすることができた。

\section{参 考 文 献}

1) C. Yatomi, Int. J of Solid Structure, 19, 183 (1983).

2) 阿部孝弘, 矢富盟祥, 橋本堅一, 材料, 47, 1059 (1998).

3) 橋本堅一, 阿部孝弘, 矢富盟祥, 土木学会構造工学論文 集, 44A, 437 (1998).

4 ) 橋本堅一, 矢富盟祥, 石田啓, 土木学会論文集, No.513/I-31,17 (1995).

5 ) A. A. Griffith, Proceedings of 1 st International Congress for Applied Mechanics, Delft, 53 (1924). 